\title{
Faktor-Fator yang Memengaruhi Tingkat Kepatuhan Wajib Pajak Orang Pribadi di KPP Pratama Badung Utara
}

\author{
Gek Ayu Putu Intan Permata Dewi ${ }^{1}$ \\ Ni Ketut Lely Aryani Merkusiwati ${ }^{2}$ \\ ${ }^{1}$ Fakultas Ekonomi dan Bisnis Universitas Udayana (Unud), Bali, Indonesia \\ email: gegintan23@gmail.com / Telp. 081236585650 \\ ${ }^{2}$ Fakultas Ekonomi dan Bisnis Universitas Udayana (Unud), Bali, Indonesia
}

\begin{abstract}
ABSTRAK
Penelitian ini menggunakan 4 variabel bebas yaitu tingkat pemahaman wajibapajak, sanksi perpajakan,lingkungan wajib pajak, danakesadaran wajib pajak. Sedangkan variabel terikatnya adalah tingkat kepatuhan wajib pajak. Tujuan penelitian ialah untuk memperoleh bukti empiris pengaruh tingkat pemahaman wajib pajak, sanksi perpajakan, lingkungan wajib pajak, dan kesadaran wajib pajak pada tingkat kepatuhan wajib pajak orang pribadi.Penelitian dilakukan di Kantor Pelayanan Pajak Pratama Badung Utara. Sampel yang diperoleh sebanyak 100 responden dengan didasarkan pada teknik Random Sampling yaitu yang mengambil responden secara acak.Teknik analisis data yang digunakan ialah analisis regresi linear berganda.Hasil penelitian ini menunjukan bahwa pengaruh tingkat pemahaman wajib pajak berpengaruhpositif pada tingkat kepatuhan wajib pajak. Sanksi perpajakan, lingkungan wajib pajak, serta kesadaran wajib pajak memiliki pengaruh negatif pada tingkat kepatuhan wajib pajak.

Kata kunci: Pemahaman wajib pajak, sanksi perpajakan, lingkungan wajib pajak, kesadaran wajib pajak, kepatuhan wajib pajak.
\end{abstract}

\begin{abstract}
This study consists of 4 independent variables namely the level of understanding of taxpayers, tax sanctions, taxpayer environment, and taxpayer awareness. While the dependent variable is the level of taxpayer compliance. The purpose of the study is to obtain empirical evidence of the influence of the level of understanding of taxpayers, tax penalties, taxpayer environment, and taxpayer awareness at the level of individual taxpayer compliance. The study was conducted at Tax Office Pratama Badung Utara. Samples obtained as many as 100 respondents based on random sampling technique that is taking the respondents randomly. The analysis technique is used multiple linear regression analysis. The results of this study indicate that the influence of the level of understanding taxpayers have a positive effect on taxpayer compliance level. Taxation sanctions, taxpayer environment, and taxpayer awareness have a negative effect on taxpayer compliance level.

Keywords: Understanding of taxpayers, taxation sanctions, environmental taxpayers, taxpayer awareness, taxpayer compliance.
\end{abstract}

\section{PENDAHULUAN}

Pajak ialah penyumbang terbesar pada pemerintahan pusat dan juga pemerintahan daerah. Pajak menjadi sektor yang tergolong mudah dalam pemungutannya, karena didukung oleh Undang-Undang Perpajakan yang berlaku. Pajak merupakan iuran dari rakyat ke dalam kas negara. Pemungutan pajak didasarkan 
Gek Ayu Putu Intan Permata Dewi dan Ni Ketut Lely Aryani Merkusiwati. Faktor...

oleh undang-undang dimana rakyat tidak memeroleh kontra prestasi yang langsung bisa ditujukan serta dipergunakan guna membayar pengeluaran umum. Pajak memiliki beberapa fungsi yakni fungsi budgetair dan fungsi regulerend. Fungsi budgetair ialah pajak memiliki fungsi sebagai sumber dana bagi pemerintah guna membiayai pengeluaran - pengeluarannya, sedangkan fungsi regulerend ialah fungsi pajak sebagai alat guna mengatur atau melaksanakan kebijakan pemerintah pada bidang sosial dan ekonomi (Mardiasmo, 2016). Agar penerimaan pendapatan pajak dapat berlangsung secara maksimal, tentunya dibutuhkan kesadaran masyarakat untuk mematuhi kewajiban perpajakan yang berlaku (Fuadi, 2013). Ketidakpatuhan membayar pajak dianggap sebagai tantangan serius, yang dapat melemahkan administrasi perpajakan dan kinerja penerimaan pajak (Heenkenda et al, 2016).

Permasalahan tentang kepatuhan wajib pajak ialah permasalahan yang sangat serius diIndonesia, karena apabila Wajib Pajak tidak mematuhi maka keinginan untuk melakukan tindakan penghindaran, pengelakan serta pelalaian pajak akan timbul, dan pada akhirnya akan dapat merugikan negara karena berkurangnya penerimaan pajak yang merupakan pendapatan utama suatu negara.

Terdapat dua faktor yang mempengaruhi kepatuhan wajib pajak yakni faktor internal dan faktor eksternal. Faktor internal yaitu faktor yang berasal dari diri. Wajib Pajak sendiri, sedangkan faktor eksternal adalah faktor yang berasal dari luar diri Wajib Pajak. Adapun contoh faktor eksternal ialah seperti situasi serta lingkungan disekitar Wajib Pajak (Heenkendaet al, 2016).

Self assessment merupakan sebuah sistem dalam pemungutan pajak yang 
dimana memberi kewenangan kepada wajib pajak untuk menghitung sendiri besarnya pajak yang terutang (Mardiasmo, 2016).Sistem self assessment telah diterima secara luas dalam pemungutan pajak di dunia (Gambo, et al, 2014).Sistem ini diharapkan dapat meningkatkan pemahaman Wajib Pajak atas peraturan perpajakan. Tingkat pemahaman perpajakan menjadi salah satu faktor potensial bagi pemerintah dalam meningkatkan kepatuhan Wajib Pajak untuk memenuhi kewajiban perpajakannya. Tanpa adanya pemahaman tentang pajak dan manfaatnyatidak mungkin orang secara ikhlas membayar pajak (Susilawati dan Budiartha, 2013).Menurut Layata dan Setiawan (2014), kepatuhan wajib pajak menjadi salah satu dasar penting dalam pengembangan dan kelancaran pemerintah daripada keberhasilan sistem self assessment sendiri.

Bandura (1977) dalam Robbins (1996) menyatakan bahwa lingkungan masyarakat bias hubungkan dengan teori pembelajaran sosial. Teori ini sangat relevan dengan lingkungan dimana Wajib Pajak tersebut berada. Dikatakan relevan karena seseorang akan taat membayar pajak tepat pada waktunya, apabila dalam pengamatan dan pengalamannya menunjukkan secara langsung bahwa hasil pungutan pajak telah memberikan kontribusi nyata pada pembangunan diwilayahnya.

Menurut Susilawati dan Budiartha (2013) bahwa pemahaman wajib pajak, sanksi perpajakan, lingkungan wajib pajakdan kesadaran wajib pajak berpengaruh positif terhadap kepatuhan wajib pajak. KPP Pratama Badung Utara adalah salah satu kantor administrasi pajak. Alasan peneliti memilih KPP ini sebagai lokasi penelitian dikarenakan tingkat kepatuhan wajib pajak orang pribadinya masih 
kecil.

Tabel 1.

\begin{tabular}{|c|c|c|c|c|c|}
\hline \multicolumn{6}{|c|}{$\begin{array}{c}\text { Rasio Kepatuhan Wajib Pajak Orang Pribadi (WPOP) di KPP Pratama } \\
\text { Badung Utara pada Tahun } 2013-2017\end{array}$} \\
\hline Uraian & 2013 & 2014 & 2015 & 2016 & $\begin{array}{c}2017 \\
\text { (per akhir Oktober) }\end{array}$ \\
\hline WPOP Terdaftar & 49.205 & 53.124 & 57.060 & 60.528 & 63.664 \\
\hline SPT WPOP Masuk & 23.714 & 24.515 & 25.001 & 26.590 & 26.182 \\
\hline Rasio Kepatuhan* & $48,19 \%$ & $46,15 \%$ & $43,82 \%$ & $43,93 \%$ & $41,13 \%$ \\
\hline
\end{tabular}

*Rasio Kepatuhan $=$ SPT WPOP Masuk $/$ WPOP Terdaftar

Sumber: KPP Pratama Badung Utara, 2017 (data diolah)

Teori atribusi menyatakan bahwa seseorang dalam menentukan tingkat kepatuhan atau tidaknya wajib pajak orang pribadi dalam memenuhi kewajiban perpajakannya dipengaruhi oleh faktor internal maupun eksternal. Faktor internal yang memengaruhi tingkat kepatuhan wajib pajak orang pribadi antara lain tingkat pemahaman wajib pajak dan kesadaran wajib pajak. Berbeda dengan faktor internal, faktor eksternal yang memengaruhi tingkat kepatuhan wajib pajak orang pribadi antara lain sanksi perpajakan dan lingkungan wajib pajak.

Pajak memiliki beberapa fungsi yakni 1) Fungsi budgetair atau yang disebut juga sebagai fungsi penerimaan dan sumber utama kas negara, ialah fungsi pajak sebagai sumber dana yang diperuntukkan bagi pembiayaan pengeluaran pengeluaran pemerintah. Contoh yaitu dimasukkannya pajak dalam APBN sebagai penerimaan dalam negeri. 2) Fungsi regulerend atauyang sering disebut sebagai fungsi mengatur/alat pengatur kegiatan ekonomi. Pajak memiliki peran sebagai alat guna mengatur atau melaksanakan kebijakan dibidang sosial maupun ekonomi.

Salah satu contoh yakni pengenaan pajak yang tinggi terhadap minuman keras, sehingga diharapkan konsumsi terhadap minuman keras dapat 
ditekan.Begitu pula halnya dengan barang mewah. 1) Fungsi alokasi yaitu pajak memiliki fungsi sebagai sumber pembiayaan pembangunan. Kas negara yang bersumber dari pajak yang sudah terkumpul harus dialokasikan untuk pembiayaan pembangunan pada segala bidang. 2) Fungsi distribusi yakni fungsi pajak sebagai alat pemerataan pendapatan. Wajib pajak harus membayar pajak, dimana pajak yang telah terkumpul didalam kas negara tersebut digunakan sebagai biaya pembangunan dalam berbagai bidang. Penggunaan pajak guna biaya pembangunan tersebut, harus merata ke seluruh pelosok tanah air sehingga seluruh lapisan masyarakat dapat merasakan dan menikmati.

Mardiasmo (2016) menyatakan bahwa pajak merupakan iuran rakyat pada kas negara yang didasari oleh undang - undang dengan tidak memperoleh kontraprestasi yang dapat langsung ditunjukkan dan yang digunakan guna membayar pengeluaran umum.Menurut UU No. 6 tahun 1983 yang telah disempurnakan menjadi UU No. 16 tahun 2009 pasal 1 nomor 1 yakni mengenai ketentuan umum serta tata cara perpajakan. "Pajak adalah kontribusi wajib pajak kepada negara yang terutang oleh orang pribadi atau badan yang bersifat memaksa berdasarkan undang - undang, dengan tidak mendapatkan imbalan secara langsung dan digunakan untuk keperluan negara bagi sebesar - besarnya kemakmuran rakyat”.

Sanksi menjadi pagar pembatas yang nyata dalam pelaksanaan suatu peraturan, yang bermaterikan hak dan kewajiban. Sanksi ialah wujud dari pelanggaran atas hak suatu pihak atau tidak dipenuhinya kewajiban yang telah ditentukan berdasarkan undang - undang maupun peraturan turunannya. Sanksi 
Gek Ayu Putu Intan Permata Dewi dan Ni Ketut Lely Aryani Merkusiwati. Faktor...

pajak memiliki peran penting guna memberikan pelajaran bagi pelanggar pajak agar tidak meremehkan peraturan perpajakan (Yasa dan Jati, 2017). Pada UU perpajakan terdapat dua macam sanksi, yakni sanksi administrasi dan sanksi pidana. Ancaman terhadap pelanggaran suatu norma perpajakan ada yang diancam dengan sanksi administrasi saja, ada yang diancam dengan sanksi pidana saja, dan ada pula yang diancam dengan sanksi administrasi dan sanksi pidana (Mardiasmo, 2016). Penelitian ini juga didukung oleh penelitian - penelitian sebelumnya sebagai kajian empiris, yaitu Cindy Jotopurnomo dan Yenni Mangoting (2013), Farid Syahril (2013), Susilawati dan Budiartha (2013), Mutia (2014), Astuti (2015), Pranata dan Setiawan (2015), Damajanti dan Karim (2017). Berdasarkan latar belakang dan penelitian-penelitian terdahulu maka dapat dapat rumuskan masalah yaitu 1) Bagaimanakah pengaruh tingkat pemahaman wajib pajak pada tingkat kepatuhan wajib pajak orang pribadi di KPP Pratama Badung Utara? 2) Bagaimanakah pengaruh sanksi perpajakan pada tingkat kepatuhan wajib pajak orang pribadi di KPP Pratama Badung Utara? 3) Bagaimanakah pengaruh lingkungan wajib pajak pada tingkat kepatuhan wajib pajak orang pribadi di KPP Pratama Badung Utara? 3)Bagaimanakah pengaruh kesadaran wajib pajak pada tingkat kepatuhan wajib pajak orang pribadi di KPP Pratama Badung Utara?

Relevansi teori atribusi dengan penelitian ini adalah bahwa seseorang dalam menentukan tingkat kepatuhan atau tidaknya wajib pajak orang pribadi dalam memenuhi kewajiban perpajakannya dipengaruhi oleh faktor internal maupun eksternal. Faktor internal merupakan faktor yang berasal dari diri Wajib Pajak 
sendiri dan berhubungan dengan karakteristik individu dalam menjalankan kewajiban perpajakannya. Faktor internal yang mempengaruhi tingkat kepatuhan wajib pajak orang pribadi dalam penelitian ini antara lain tingkat pemahaman wajib pajak dan kesadaran wajib pajak. Berbeda dengan faktor internal, faktor eksternal adalah faktor yang berasal dari luar diri Wajib Pajak, seperti situasi dan lingkungan di sekitar Wajib Pajak. Faktor eksternal yang memengaruhi tingkat kepatuhan wajib pajak orang pribadi dalam penelitian ini antara lain sanksi perpajakan dan lingkungan wajib pajak.

Menurut Punarbhawa dan Lely (2013), kepatuhan adalah bagian dari sistem self assessment karena wajib pajak bertanggung jawab atas kewajiban perpajakannya, menghitung besarnya pajak terutang serta tepat waktu membayar dan melaporkan pajak yang terutang. Kepatuhan wajib pajak dapat dilihat berdasarkan kriteria yang telah ditetapkan dalam Surat Edaran Direktorat Jendral Pajak Nomor SE-02/PJ./2008 tentang Tata Cara penetapan Wajib Pajak dengan kriteria tertentu. Wajib pajak akan ditetapkan sebagai wajib pajak patuh oleh Direktorat Jendral Pajak jika memenuhi kriteria tertentu dalam Surat Edaran tersebut. Salah satu kriteria Wajib Pajak patuh adalah tepat waktu dalam menyampaikan Surat Pemberitahuan (SPT).

Pemahaman wajib pajak sangatlah penting, setiap wajib pajak harus memiliki pemahaman tentang perpajakan guna mengetahui bagaimana cara perhitungan pajak yang harus dibayar atau pajak terutang, memahami apa itu Nomor Pokok Wajib Pajak (NPWP), bagaimana cara melaporkannya, bagaimana cara menyetornya atau membayar pajak yang harus dibayar dan pengisian surat 
Gek Ayu Putu Intan Permata Dewi dan Ni Ketut Lely Aryani Merkusiwati. Faktor...

pemberitahuan. Sistem pemungutan pajak di Indonesia adalah Self assessment system maka wajib pajak harus memiliki pemahaman yang baik tentang peraturan perpajakan yang berlaku dalam rangka memenuhi kewajiban perpajakan tersebut. Apabila wajib pajak memiliki pengetahuan yang cukup mengenai SPT, pelaporan, penghitungan, pembayaran atas pajaknya maka semua ketentuan pemenuhan kewajiban perpajakan dapat dilakukan dengan baik oleh wajib pajak.

Masruroh (2013) mengatakan bahwa pengetahuan dan pemahaman akan peraturan perpajakan adalah proses dimana wajib pajak mengetahui tentang perpajakan dan mengaplikasikan pengetahuan itu untuk membayar pajak. Pengetahuan dan pemahaman peraturan perpajakan yang dimaksud mengerti dan paham tentang ketentuan umum dan tata cara perpajakan yang meliputi tentang bagaimana cara menyampaikan surat pemberitahuan (SPT), pembayaran, tempat pembayaran, denda dan batas waktu pembayaran atau pelaporan SPT. Lerche, Pletrich (1980 dalam Razman 2005) menjelaskan bahwa jika pengetahuan dan pemahaman rendah maka kepatuhan WP terhadap peraturan yang berlaku juga rendah. Dengan demikian pemahaman tentang perpajakan berupa informasi perpajakan dan peraturan perpajakan akan meningkatkan kepatuhan sesorang dalam membayar kewajiban perpajakannya. Menurut Saad (2014) pemahaman pajak oleh wajib pajak berpengaruh pada kepatuhan membayar pajak di bawah sistem self assestment.

Menurut Mardiasmo (2016), sanksi adalah pagar pembatas yang nyata bagi pelaksanaan suatu peraturan yang bermaterikan hak dan kewajiban. Sanksi merupakan wujud dari pelanggaran atas hak suatu pihak atau tidak dipenuhinya 
kewajiban yang telah ditentukan berdasarkan undang - undang maupun peraturan turunannya. Sanksi pajak memiliki peran penting guna memberikan pelajaran bagi pelanggar pajak agar tidak meremehkan peraturan perpajakan (Yasa dan Jati, 2017). Undang - Undang perpajakan dikenal dua macam sanksi, yaitu sanksi administrasi dan sanksi pidana. Ancaman terhadap pelanggaran suatu norma perpajakan ada yang diancam dengan sanksi administrasi saja, ada yang diancam dengan sanksi pidana saja, dan ada pula yang diancam dengan sanksi administrasi dan sanksi pidana.

Sanksi Administrasi merupakan pembayaran kerugian terhadap negara yang bisa berupa denda administrasi, bunga, atau kenaikan pajak yang terhutang. Sanksi administrasi ditekankan kepada pelanggaran - pelanggaran administrasi perpajakan yang tidak mengarah kepada tindakan pidana perpajakan. Sanksi Pidana merupakan upaya terakhir dari pemerintah agar norma perpajakan benar benar dipatuhi. Sanksi pidana ini bisa timbul karena adanya tindak pidana pelanggaran yaitu tindak pidana kejahatan yaitu tindakan pidana yang mengandung unsur kesengajaan atau kelalaian/pengabaian. Sedangkan ancaman sanksi pidana dapat berupa denda pidana, pidana kurungan, atau pidana penjara.

Menurut Handayani dan Laily (2017), meskipun adanya sanksi, masih banyak terdapat wajib pajak yang lalai untuk membayar kewajibannya. Menurut Swistak (2015), perlu dipikirkan baik - baik dalam pembuatan sanksi perpajakan agar tidak terjadi penghindaran pajak oleh wajib pajak. Kesadaran wajib pajak merupakan kerelaan yang muncul dari dalam diri wajib pajak untuk membayar kewajiban perpajakannya secara ikhlas tanpa adanya paksaan meskipun wajib 
Gek Ayu Putu Intan Permata Dewi dan Ni Ketut Lely Aryani Merkusiwati. Faktor...

pajak tidak dapat menikmati secara langsung atas pajak yang dibayarkannya. Maka perlu ditumbuhkan kesadaran dari diri wajib pajak akan fungsi pajak sebagai pembiayaan negara.

Menurut Kamil (2015), wajib pajak sadar akan kewajibannya dikarenakan wajib pajak tidak merasa dirugikan dalam pemungutan pajak dan tidak dalam kondisi paksaan. Menurut Andreas dan Savitri (2015), jika wajib pajak mengerti bagaimana cara menghitung, membayar dan melaporkan kewajiban pajaknya sesuai peraturan perpajakan, akan berdampak pada meningkatnya kesadaran wajib pajak.

Mengukur kesadaran wajib pajak adalah 1) Mengetahui Fungsi Pajak, wajib pajak sadar bahwa dengan membayar pajak akan digunakan pemerintah sebagai salah satu sumber pembiayaan pelaksanaan fungsi dan tugas pemerintah secara rutin. 2) Kesadaran membayar pajak, dengan sadar membayar pajak akan dapat digunakan pemerintah sebagai dana umum pelaksanaan fungsi dan tugas pemerintah, wajib pajak sadar bahwa negara membutuhkan pembiayaan dan pajak merupakan salah satu tulang punggung negara. Kerangka konseptual penelitian ini berdasarkan uraian teori diatas adalah sebagai berikut. 


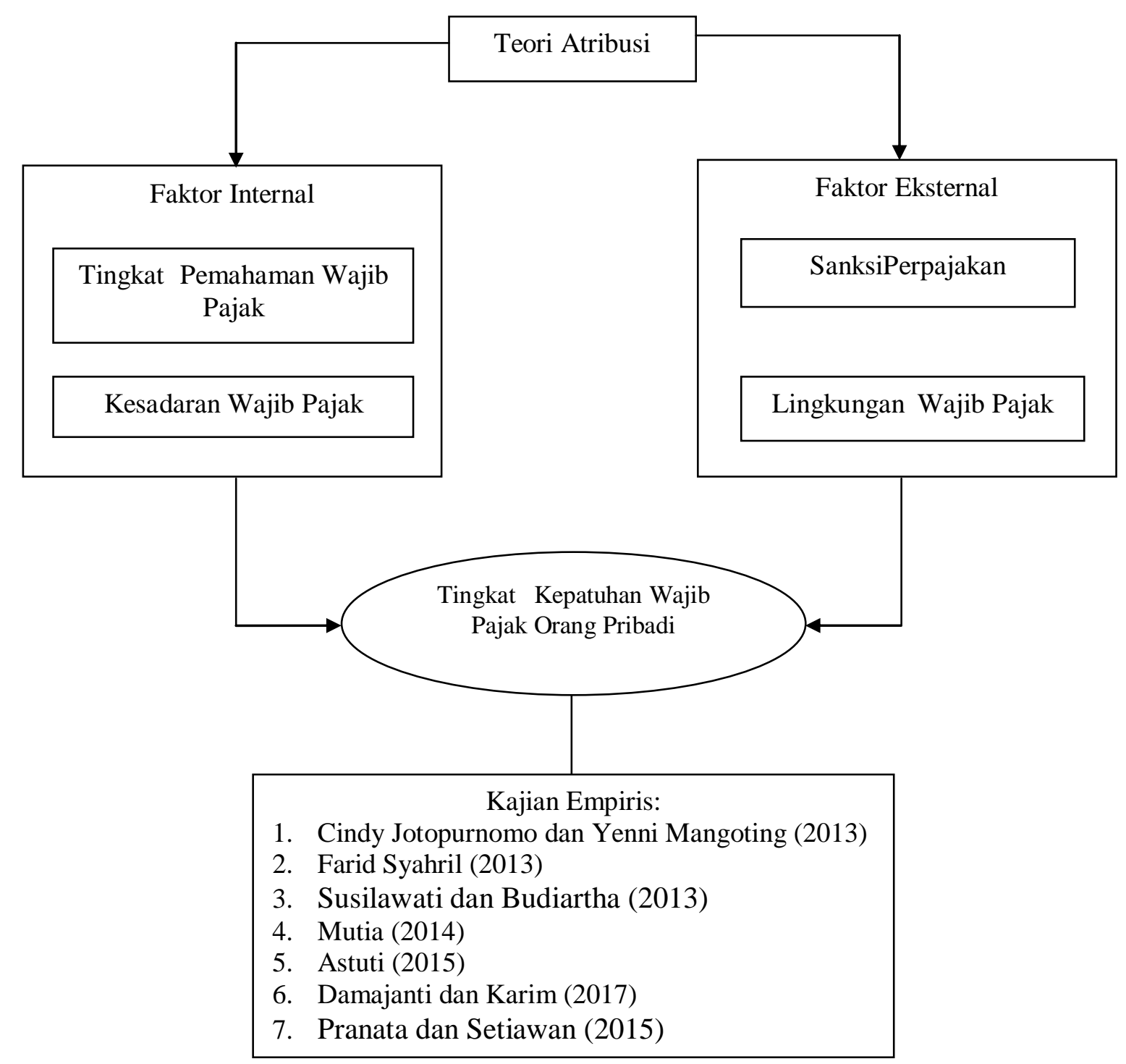

Gambar 1.

Kerangka Konseptual

Sumber: Data diolah, 2017

Berdasarkan teori atribusi, tingkat pemahaman wajib pajak merupakan penyebab internal yang dapat memengaruhi tingkat kepatuhan wajib pajak. Tingkat pemahaman wajib pajak berpengaruh positif dan signifikan terhadap tingkat kepatuhan wajib pajak. Berdasarkan pemaparan di atas, maka dapat dirumuskan hipotesis sebagai berikut. 
Gek Ayu Putu Intan Permata Dewi dan Ni Ketut Lely Aryani Merkusiwati. Faktor...

$\mathrm{H}_{1}$ : Tingkat pemahaman wajib pajak berpengaruh positif pada tingkat kepatuhan wajib pajak orang pribadi di KPP Pratama Badung Utara.

Sanksi perpajakan merupakan penyebab eksternal yang bisa memengaruhi tingkat kepatuhan wajib pajak. Adanya sanksi akan mendorong meningkatnya kepatuhan perpajakan. Sanders, et al (2008) serta Pranata dan Setiawan (2015) menyebutkan bahwa sanksi pajak memiliki pengaruh positif pada kepatuhan wajib pajak, sehingga dapat dirumuskan hipotesis sebagai berikut.

$\mathrm{H}_{2}$ : Sanksi perpajakan berpengaruh positif pada tingkat kepatuhan wajib pajak orang pribadi di KPP Pratama Badung Utara.

Lingkungan wajib pajak merupakan penyebab eksternal yang dapat memengaruhi tingkat kepatuhan wajib pajak. Lingkungan sekitar wajib pajak yang memiliki tanggung jawab untuk membayar pajak serta sosialisasi dari kantor pajak akan lebih mendukung wajib pajak tersebut untuk patuh membayar pajak. Menurut penelitian Astuti (2015), mengungkapkan bahwa lingkungan wajib pajak berpengaruh positif dan signifikan terhadap tingkat kepatuhan wajib pajak. Berdasarkan paparan diatas, dapat dirumuskan hipotesis sebagai berikut.

$\mathrm{H}_{3}$ : Lingkungan wajib pajak berpengaruhppositif pada tingkat kepatuhan wajib pajak orang pribadi diKKPP Pratama Badung Utara.

Kesadaran wajib pajak merupakan penyebab internal yang dapat memengaruhi tingkat kepatuhan wajib pajak. Semakin tinggi kesadaran wajib pajak maka pamahaman dan pelaksanaan kewajiban perpajakan semakin baik sehingga dapat meningkatkan kepatuhan wajib pajak (Mutia, 2014). Pemerintah dalam hal ini KPP Pratama Badung Utara sebagai perpanjangan tangan dari Direktorat Jenderal Pajak (DJP) harus senantiasa meningkatkan kesadaran wajib pajak dengan meningkatkan pengetahuan masyarakat khususnya wajib pajak 
mengenai perpajakan melalui penyuluhan, seminar dan berupa himbauanhimbauan tentang pentingnya membayar pajak untuk kesinambungan pembangunan, selain itu dari sisi pemerintah pun harus dapat menunjukkan kepada masyarakat bahwa pajak yang dibayarkan oleh wajib pajak benar - benar dapat dirasakan manfaatnya langsung oleh masyarakat. Menurut penelitian Mutia (2014), mengungkapkan bahwa kesadaran wajib pajak berpengaruh signifikan dan positif terhadap kepatuhan wajib pajak. Berdasarkan pemaparan di atas, maka dapat dirumuskan hipotesis sebagai berikut.

$\mathrm{H}_{4}$ : Kesadarn wajib pajak berpengaruh positif pada tinkat kepatuhan wajib pajak orang pribadi di KPP Pratama Badung Utara.

\section{METODE PENELITIAN}

Desain penelitin dalam penelitian ini adalah penelitian kuantitatif asosiatif dengan tipe kausalitas. Penelitian ini dilakukan di KPP Pratama Badung Utara. Objek pada penelitian ialah wajib pajak orang pribadi yang terdaftar di KPP Pratama Badung Utara.Tingkat Kepatuhan Wajib Pajak merupakan variabel terikat yang digunakan dalam penelitian. Variabel bebas yang digunakan dalam penelitian ini adalah tingkat pemahaman wajib pajak, sanksi perpajakan, lingkungan wajib pajak, serta kesadaran wajibbpajak.

Populasi dalam penelitian ini ialah Waiib Pajak Orang Pribadi pada Kantor Pelayanan Pajak Pratama Badung Utara pada periode tahun 2017 yang berjumlah 63.664. Teknik pengambilan sampel dalam penelitian ini adalah Random Sampling. Random Sampling adalah pengambilan sampel dari populasi secara acak tanpa memperhatikan strata yang ada dalam populasi itu (Sugiyono, 2017). Jadi dalam penelitian ini peneliti akan datang ke KPP Pratama Badung Utara, 
Gek Ayu Putu Intan Permata Dewi dan Ni Ketut Lely Aryani Merkusiwati. Faktor...

kemudian peneliti akan mendatangi wajib pajak orang pribadi saat itu disana secara acak dan meminta untuk mengisi kuesioner.

Jenis data yang digunakan dalam penelitian ini adalah data kuantitatif dan data kualitatif. Data kuantitatif yang digunakan dalam penelitian ini adalah pernyataan responden yang dinyatakan dengan angka - angka meliputi skor nilai dari jawaban responden dalam kuesioner penelitian. Data kualitatif dalam penelitian ini adalah berupa informasi - informasi KPP Badung Utara dan pernyataan responden yang dinyatakan dengan sangat setuju, setuju, netral, tidak setuju dan sangat tidak setuju.

Sumber data yang digunakan dalam penelitian ini adalah sumber data primer dan sekunder. Data primer dalam penelitian ini ialah jawaban yang diberikan oleh responden berupa pernyataan dalam kuesioner. Data sekunder dalam penelitian ini adalah data jumlah Wajib Pajak yang terdaftar di KPP Pratama Badung Utara.

Metode pengumpulan data yang digunakan dalam penelitian ini adalah metode survey dengan teknik kuesioner, yaitu teknik pengumpulan data yang dilakukan dengan cara memberikan pertanyaan atau penyataan tertulis kepada responden untuk dijawabnya (Sugiyono, 2017). Teknik analisis data yang digunakan adalah analisis regresi linear berganda, karena terdiri dari satu variabel dependen dan beberapa variabel independen. Model regresi linear berganda ditunjukkan oleh persamaan regresi berikut.

$$
Y=\alpha+\beta_{1} X_{1}+\beta_{2} X_{2}+\beta_{3} X_{3}+\beta_{4} X_{4}+\varepsilon
$$


Keterangan:

Y : Tingkat kepatuhan wajib pajak

$\alpha \quad$ :aKonstanta

$\beta \quad$ : Koefisienrregresi variabel $\mathrm{X}_{1}-\mathrm{X}_{4}$

$\mathrm{X}_{1} \quad$ : TingkatPPemahaman Wajib pajak

$\mathrm{X}_{2} \quad$ : SanksipPerpajakan

$\mathrm{X}_{3} \quad$ : Lingkungan wajib pajak

$\mathrm{X}_{4} \quad$ : Kesadaran wajib pajak

$\varepsilon \quad:$ Errorterm

Uji hipotesis dalam penelitian ini menggunakan uji t. Uji t menunjukkan seberapa jauh pengaruh satu variabel independen secara individual dalam menerangkan variabel dependen (Ghozali, 2016:97). Tingkat signifikansi yang ditetapkan dalam penelitian ini adalah $0,05(\alpha=5 \%)$.

\section{HASIL DAN PEMBAHASAN}

Kantor Pelayanan Pajak (KPP) Pratama Badung Utara merupakan instansi vertikal Direktorat Jenderal Pajak yang melakukan kegiatan pelayanan terhadap Wajib Pajak antara lain dengan memberikan informasi prosedur dan peraturan kepada Wajib Pajak, pemberian Nomor Pokok Wajib Pajak (NPWP) dan Nomor Pengukuhan Pengusaha Kena Pajak (NPPKP), penghapusan NPWP, penyediaan formulir perpajakan, permohonan keberatan dan penyuluhan, maka total sampel dalam penelitian ini adalah 100 responden.

Gambaran umum mengenai objek penelitian ditunjukkan oleh statistik deskriptif. Informasi mengenai hasil statistik deskriptif ditunjukkan pada tabel 2. 
Tabel 2.

Hasil Statistik Deskriptif Variabel Penelitian

\begin{tabular}{|c|c|c|c|c|c|c|}
\hline & $\begin{array}{c}\text { Variabel } \\
\text { Pernyataan ke- }\end{array}$ & $\mathbf{N}$ & Minimum & Maximum & Mean & $\begin{array}{l}\text { Standar } \\
\text { Deviasi }\end{array}$ \\
\hline \multicolumn{7}{|c|}{$\begin{array}{l}\text { Tingkat Kepatuhan Wajib Pajak } \\
\text { Orang Pribadi }\end{array}$} \\
\hline a) & 1 & 100 & 1,00 & 5,00 & 2,22 & 1,31 \\
\hline b) & 2 & 100 & 1,00 & 5,00 & 2,01 & 1,29 \\
\hline c) & 3 & 100 & 1,00 & 5,00 & 2,25 & 1,38 \\
\hline d) & 4 & 100 & 1,00 & 5,00 & 2,06 & 1,27 \\
\hline e) & 5 & 100 & 1,00 & 5,00 & 2,55 & 1,45 \\
\hline f) & 6 & 100 & 1,00 & 5,00 & 1,88 & 1,23 \\
\hline g) & 7 & 100 & 1,00 & 5,00 & 2,52 & 1,56 \\
\hline \multicolumn{7}{|c|}{ Tingkat Pemahaman Wajib Pajak } \\
\hline a) & 1 & 100 & 1,00 & 5,00 & 1,83 & 0,73 \\
\hline b) & 2 & 100 & 1,00 & 5,00 & 2,24 & 0,94 \\
\hline c) & 3 & 100 & 1,00 & 5,00 & 2,13 & 0,79 \\
\hline d) & 4 & 100 & 1,00 & 5,00 & 2,32 & 0,93 \\
\hline \multicolumn{7}{|c|}{ Sanksi Perpajakan } \\
\hline a) & 1 & 100 & 1,00 & 4,00 & 1,87 & 0,81 \\
\hline b) & 2 & 100 & 1,00 & 4,00 & 1,69 & 0,61 \\
\hline c) & 3 & 100 & 1,00 & 4,00 & 1,75 & 0,72 \\
\hline d) & 4 & 100 & 1,00 & 5,00 & 1,61 & 0,72 \\
\hline e) & 5 & 100 & 1,00 & 4,00 & 1,65 & 0,70 \\
\hline \multicolumn{7}{|c|}{ Lingkungan Wajib Pajak } \\
\hline a) & 1 & 100 & 1,00 & 3,00 & 1,34 & 0,48 \\
\hline b) & 2 & 100 & 1,00 & 3,00 & 1,54 & 0,58 \\
\hline c) & 3 & 100 & 1,00 & 4,00 & 1,47 & 0,54 \\
\hline \multicolumn{7}{|c|}{ Kesadaran Wajib Pajak } \\
\hline a) & 1 & 100 & 1,00 & 2,00 & 1,34 & 0,48 \\
\hline b) & 2 & 100 & 1,00 & 3,00 & 1,54 & 0,58 \\
\hline c) & 3 & 100 & 1,00 & 3,00 & 1,47 & 0,54 \\
\hline d) & 4 & 100 & 1,00 & 4,00 & 1,58 & 0,62 \\
\hline e) & 5 & 100 & 1,00 & 3,00 & 1,71 & 0,61 \\
\hline f) & 6 & 100 & 1,00 & 3,00 & 1,70 & 0,54 \\
\hline Valid $\mathrm{N}$ & (listwise) & 100 & & & & \\
\hline
\end{tabular}

Sumber: Data diolah, 2017

Berdasarkan Tabel 2, terlihat bahwa variabel tingkat kepatuhan wajib pajak orang pribadi memiliki tujuh pernyataan. Pernyataan pertama yakni wajib pajak menyediakan data - data yang lengkap saat pemeriksaan pajak 
dilaksanakan. Pernyataan ini memiliki nilai minimum sebesar 1 serta nilai maksimum sebesar 5, dengan nilai rata - rata sebesar2,22. Nilai rata - rata sebesar 2,22 menunjukkan bahwa sedikit wajib pajak yang menyediakan data-data secara lengkap saat pemeriksaan pajak dilaksanakan. Pernyataan kedua yakni wajib pajak mengisi formulir pajak dengan lengkap dan jelas. Pernyataan ini memiliki nilai minimum 1 dan nilai maksimum 5, dengan nilai rata - rata 2,01. Nilai rata rata 2,01 menunjukkan bahwa sedikit wajib pajak yang mengisi formulir pajak dengan lengkap dan jelas. Pernyataan ketiga yakni wajib pajak menghitung pajak yang terutang dengan jumlah yang benar. Pernyataan ini memiliki nilai minimum 1ddan nilaimmaksimum 5, dengan nilai rata - rata 2,25. Nilai rata-rata sebesar 2,25 berarti terdapat sedikit wajibppajak yang menghitung pajak terutangnya dengan jumlah yang benar. Pernyataan keempat yakni wajib pajak membayar pajak yang terutang tepat waktu. Pernyataan ini memiliki nilai minimumm1 dan nilai maksimum 5, dengan nilai rata-rata 2,06. Nilai rata - rata sebesar 2,06 menunjukkan bahwa sedikit wajib pajak yang membayar pajak terutangnya tepat pada waktunya.

Pernyataan kelima yakni wajib pajak tepat waktu dalam menyampaikan surat pemberitahuan (SPT). Pernyataan ini memiliki nilai minimum 1 dannilai maksimum 5, dengan nilai rata-rata 2,55. Nilai rata-rata sebesar 2,55 menunjukkan bahwa sedikit wajib pajak yang tepat waktu dalam menyampaikan SPT. Pernyataan keenam yakni wajib pajak membayar pajak sesuai dengan tarif yang dibebankan. Pernyataan ini memiliki nilai minimum 1 dan nilai maksimum 5, dengan nilai rata-rata 1,88. Rata-rata sejumlah 1,88 menunjukkan bahwa sedikit 
Gek Ayu Putu Intan Permata Dewi dan Ni Ketut Lely Aryani Merkusiwati. Faktor...

wajib pajak yang membayar pajak sesuai dengan tarif yang dibebankan. Pernyataan ketujuh yakni wajib pajak tidak melakukan penunggakan dalam membayar pajak. Pernyataan ini memiliki nilai minimum 1 dan nilai maksimum 5, dengan nilai rata-rata sebesar 2,52. Nilai rata-rata sebesar 2,52 menunjukkan bahwa sedikit wajib pajak yang melakukan penunggakan dalam membayar pajak.

Variabel tingkat pemahaman wajib pajak memiliki empat pernyataan. Pernyataan pertama yakni apabilaasaya mematuhi perpajakan,aakan sangat mudah dalam melaksanakan kewajiban perpajakannya. Pernyataan ini memiliki nilai minimumm1 dan maksimum 5, dengan nilai rrata-rata 1,83. Nilai rata-rata sebesar 1,83 menunjukkan bahwa sedikit wajib pajak yang paham pentingnya mematuhi perpajakan. Pernyataan kedua yakni wajib pajak harus menyerahkanSSPOPnya selambat-lambatnya 30 hari setelah tanggal diterimanya SPOP. Pernyataan ini memiliki nilai minimum sebesar 1 dan maksimum sebesar 5, dengan nilai rata-rata sebesar 2,24. Nilai rata-ratassebesar 2,24 menunjukkan bahwa sedikit wajib pajak yang paham Surat Pemberitahuan Objek Pajak (SPOP) diserahkan selambatlambatnya 30 hari.

Pernyataan ketiga yakni pajak terutang harusddilunasi selambata-lambatnya 6 bulanssejak diterimanya surat pemberitahuan pajak terutang (SPPT) olehwwajib pajak. Pernyataan ini memiliki nilai minimum 1 dan nilaiMmaksimum 5, dengan nilai rata-rata 2,13. Nilai rata-rata sebesar 2,13 menunjukkan bahwa sedikit wajib pajak yang paham pajak terutang harus dilunasi selambat-lambatnya 6 bulan sejak diterimanya SPPT. Pernyataan keempat yakni pajak yanggterutang pada saat jatuh tempo tidak dibayar akan dikenakan denda sebesar $2 \%$ sebulan. Pernyataan ini 
memiliki nilai minimum 1 dan nilai maksimum 5, dengan nilai rata-rata 2,32. Nilai rata-rata 2,32 menunjukkan bahwa sedikit wajib pajak yang paham pajak yang terutang pada saat jatuh tempo tidak dibayar akan dikenakan denda.

Variabel sanksi perpajakan memiliki 5 pernyataan. Pernyataan pertama yakni sanksi pajak akan diterima wajibppajak apabila terlambat ataudtidak memenuhi kewajiban pajaknya. Pernyataan ini memiliki nilaimminimum yakni 1 dan nilai maksimum 4, dan nilairrata-rata sebesar 1,87. Nilai rata-rata sejumlah 1,87 menunjukkan bahwa sedikit wajib pajak yang setuju pemberian sanksi jika terlambat memenuhi kewajiban perpajakan. Pernyataan kedua yakni wajib pajak akan diberi sanksi jika menyembunyikan objek pajaknya. Pernyataan ini memiliki nilai minimum sebesar 1 dannilai maksimum sebesar 4 , dengan nilai rata-rata 1,69. Nilai rata-rata sebesar 1,69 menunjukkan bahwa sedikit wajib pajak yang setuju pemberian sanksi jika menyembunyikan objek pajaknya.

Pernyataan ketiga yakniwajib pajak akan dikenakan sanksi administrasi apabilatidak membayar atau kurang membayar pajak terutang ketika telah jatuh tempo. Pernyataan ini memiliki nilai minimum 1 serta nilai maksimum 4, nilai rata-rata sebesar 1,75. Nilai rata-rata sebesar 1,75 menunjukkan bahwa sedikit wajib pajak yang setuju pemberian sanksi administrasi jika tidak membayar/kurang membayar pajak terutang saat jatuh tempo. Pernyataan keempat yakni wajib pajak akan diberi sanksi pidana jika dengan sengaja memerlihatkan dokumen palsu atau dipalsukan. Pernyataan ini memiliki nilai minimum 1 dan nilai maksimum 5, nilai rata-rata 1,61. Nilai rata-rata sebesar 1,61 menunjukkan bahwa sedikit wajib pajak yang setuju pemberian sanksi pidana jika dengan 
Gek Ayu Putu Intan Permata Dewi dan Ni Ketut Lely Aryani Merkusiwati. Faktor...

sengaja memerlihatkan dokumen palsu atau dipalsukan. Pernyataan kelima yakni wajib pajak akan diberikan sanksi sesuai dengan ketentuan dan peraturan yang berlaku. Pernyataan ini memiliki nilai minimum sebesar 1 serta nilai maksimum sebesar 4, dengan nilai rata-rata sebesar 1,65. Nilai rata-rata sebesar 1,65 menunjukkan bahwa sedikit wajib pajak yang setuju pemberian sanksi sesuai dengan ketentuan dan peraturan yang berlaku.

Variabel lingkungan wajib pajak memiliki 3 pernyataan. Pernyataan pertama yakni saya akan tetap membayar pajak walaupun masyarakat disekitar saya tidak bayar pajak. Pernyataan ini memiliki nilai minimum sebesar 1 dan nilai maksimum sebesar 3, dengan nilai rata-rata sebesar 1,89. Nilai rata-rata sebesar 1,89 menunjukkan bahwa sedikit wajib pajak yang setuju untuk tetap membayar pajak walaupun masyarakat disekitarnya tidak membayar pajak. Pernyataan kedua yakni masyarakat di sekitar rumah saya telah melaksanakan kewajiban perpajakannya dengan benar. Pernyataan ini memiliki nilai minimum sebesar 1 dan nilai maksimum sebesar 3, dengan nilai rata-rata sebesar 1,88 . Nilai rata-rata sebesar 1,88 menunjukkan bahwa sedikit wajib pajak yang masyarakat di sekitar rumahnya melaksanakan kewajiban perpajakannya dengan benar. Pernyataan ketiga yakni saya pernah mendapatkan sosialisasi pajak dari kantor pajak setempat. Pernyataan ini memiliki nilai minimum sebesar 1 dan nilai maksimum sebesar 4, dengan nilai rata-rata sebesar 2,19. Nilai rata-rata sebesar 2,19 menunjukkan bahwa sedikit wajib pajak yang pernah mendapatkan sosialisasi pajak dari kantor pajak setempat. 
Variabel kesadaran wajib pajak memiliki 6 pernyataan. Pernyataan pertama yakni pajak adalah sumber dana terbesar bagi negara. Pernyataan ini memiliki nilai minimum sebesar 1 dan nilai maksimum sebesar 2 , dengan nilai rata-rata sebesar 1,34. Nilai rata-rata sebesar 1,34 menunjukkan bahwa sedikit wajib pajak yang setuju, pajak adalah sumber dana terbesar bagi negara. Pernyataan kedua yakni pajak memiliki fungsi sebagai alat untuk mengatur atau melaksanakan kebijakan dibidang sosial maupun ekonomi, pajak sebagai sumber dana untuk pembiayaan pembangunan, pajak merupakan alat pemerataan pendapatan. Pernyataan ini memiliki nilai minimum 1 dan nilai maksimum sebesaree3, dan nilai rata-ratanya yakni sebesar 1,54. Nilai rata-rata 1,54 menunjukkan bahwa sedikit wajib pajak yang setuju, pajak memiliki fungsi sebagai alat untuk mengatur atau melaksanakan kebijakan dibidang sosial dan ekonomi, pajak ialah sumber dana untuk pembiayaan pembangunan, serta pajak sebagai alat pemerataan pendapatan.

Pernyataan ketiga yakni kesadaran wajib pajak bahwammelakukan kepatuhan pajak berarti berpartisipasi dalamp penyelenggaraan Negara. Pernyataan ini memiliki nilai minimummsebesar 1 dan nilai maksimum sebesar 3 , dengan nilai rata-rata sebesar 1,47. Nilai rata-rata sebesar 1,47 menunjukkan bahwa sedikit wajib pajak yang setuju, kesadaran wajib pajak bahwa melakukan kepatuhan pajak berarti berpartisipasi dalam penyelenggaraan Negara. Pernyataan keempat yakni kesadaran wajib pajak untuk memenuhi kewajiban pajak tepat waktu tanpa pengaruh orang lain dan sadar bahwa pajak digunakan untuk pembangunan sarana publik. Pernyataan ini memilikinnilai minimum 1 dan nilai 
Gek Ayu Putu Intan Permata Dewi dan Ni Ketut Lely Aryani Merkusiwati. Faktor...

maksimum sebesar 4, dengannnilai rata-rata sebesar 1,58. Nilai rata-rata sebesar 1,58 menunjukkan bahwa sedikit wajib pajak yang setuju kesadaranwwajib pajak untuk memenuhikkewajiban pajak tepat waktu tanpa pengaruh orang lain dan sadar bahwa pajak digunakan untuk pembangunan sarana publik. Pernyataan kelima yakni dalam kondisi keuangan seperti apapun wajib pajak akan tetap membayar pajak sesuai dengan peraturan yang berlaku. Pernyataan ini memiliki nilai minimum yakni sebesar 1 serta nilai maksimum sebesar 3 , dengan nilai ratarata sebesar 1,71. Nilai rata-rata sebesar 1,71 menunjukkan bahwa sedikit wajib pajak yang setuju, bagaimanapun kondisi keuangan wajib pajak, wajib pajak akan tetap membayar pajak sesuai dengan peraturan yang berlaku. Pernyataan keenam yakni saya tidak akan mencurangi formulir, saya akan mengisi sesuai dengan penghasilan yang saya hasilkan. Pernyataan ini memiliki nilai minimum sebesar 1 dan nilai maksimum sebesar 3, dengan nilai rata-rata sebesar 1,70. Nilai rata-rata sebesar 1,70 menunjukkan bahwa sedikit wajib pajak yang setuju, wajib pajak tidak akan mencurangiformulir, wajib pajak akan mengisi sesuai dengan penghasilan yang wajib pajak hasilkan.

Syarat minimum suatu kuesioner untuk memenuhi validitas adalah jika korelasi antar suatu butir dengan skor total tersebut positif dan besarnya 0,30 ke atas (Sugiyono, 2017:178). Berdasarkan hasil Tabel 3, hasil koefisien korelasi pada semua pernyataan variabel bebas maupun variabel terikat yakni lebih dari 0.30. Ini berarti bahwa semua pernyataan valid, sehingga dapat digunakan dalam penelitian ini. 
ISSN: 2302-8556

E-Jurnal Akuntansi Universitas Udayana

Vol.23.2. Mei (2018): 1277-1304

Tabel 3.

Hasil Uji Validitas

\begin{tabular}{lccc}
\hline \multicolumn{1}{c}{ Variabel } & Item & $\begin{array}{c}\text { Koefisien } \\
\text { Korelasi }\end{array}$ & Keterangan \\
\hline Tingkat Kepatuhan Wajib Pajak & Y.1a & 0.757 & Validd \\
Orang Pribadi & Y.2a & 0.802 & Valida \\
& Y.3a & 0.784 & Valida \\
& Y.4 & 0.785 & Valida \\
& Y.5 & 0.634 & Valida \\
Tingkat Pemahaman Wajib & Y.6 & 0.747 & Valida \\
Pajak & Y.7 & 0.644 & Valida \\
& X1.1 & 0.646 & Valida \\
Sanksi Perpajakan & X1.2 & 0.880 & Valida \\
& X1.3 & 0.819 & Valida \\
& X1.4 & 0.778 & Valida \\
& X2.1 & 0.672 & Valida \\
Xingkungan Wajib Pajak & X2.2 & 0.760 & Valida \\
& X2.3 & 0.820 & Valida \\
& X2.5 & 0.754 & Valida \\
& X3.1 & 0.722 & Valida \\
Kesadaran Wajib Pajak & X3.2 & 0.877 & Valida \\
& X3.3 & 0.892 & Valida \\
& X4.1 & 0.809 & Valida \\
& X4.2 & 0.562 & Valida \\
& X4.3 & 0.685 & Valida \\
& X4.4 & 0.751 & Valida \\
& X4.5 & 0.644 & Valida \\
& & 0.774 & Valida \\
\hline
\end{tabular}

Sumber: Data diolah, 2017

Adapun hasil uji reliabilitas dengan Cronbach Alpha disajikan pada Tabel 4.

Tabel 4.

Hasil Uji Reliabilitas

\begin{tabular}{lcc}
\hline \multicolumn{1}{c}{ Variabel } & Koefisien Alpha Cronbach & Keterangan \\
\hline $\begin{array}{l}\text { Tingkat Kepatuhan Wajib } \\
\text { Pajak Orang Pribadi }\end{array}$ & 0,854 & Reliabel \\
Tingkat Pemahaman Wajib & 0,790 & Reliabel \\
Pajak & 0,794 & Reliabel \\
Sanksi Perpajakan & 0,794 & Reliabel \\
Lingkungan Wajib Pajak & 0,776 & Reliabel \\
Kesadaran Wajib Pajak & &
\end{tabular}

Pada Tabel 4 terlihat bahwa Cronbach Alpha dari masing-masing variabel lebih besar dari 0,7. Ini berarti bahwa alatuukur yang digunakan dalam penelitian adalah reliabel. 
Gek Ayu Putu Intan Permata Dewi dan Ni Ketut Lely Aryani Merkusiwati. Faktor...

Berdasarkan hasil uji normalitas terlihat bahwa nilai Asymp.Sig.(2tailed)untuk data variabel sebesar 0,355. Hasil tersebut lebih besar dari nilai alpha 0,05 sehingga dapat dikatakan data residual terdistribusi normal.

Berdasarkan hasil uji multikolinearitas terlihat bahwa nilai VIFnya dibawah 10 atau nilai tolerancenya di atas 0,10 . Maka model regresi tidak terjadi multikolinearitas. Berdasarkan hasil uji heteroskedastisitas terlihat bahwa nilai signifikansi masing-masing variabel pada model regresi nilainya lebih besar dari 0,05. Hal ini menunjukkan bahwa model regresi tersebut tidak mengandung heteroskedastisitas.

Tabel 5.

Hasil Analisis Regresi Linear Berganda

\begin{tabular}{|c|c|c|}
\hline Model & $\begin{array}{c}\text { Unstandardized Coefficients } \\
\beta\end{array}$ & Sig. \\
\hline (Constant) & 3,899 & 0,281 \\
\hline $\begin{array}{l}\text { Tingkat Pemahaman Wajib Pajak } \\
\text { (X1) }\end{array}$ & 1,314 & 0,000 \\
\hline Sanksi Perpajakan (X2) & $-0,055$ & 0,814 \\
\hline Lingkungan Wajib Pajak (X3) & 0,504 & 0,154 \\
\hline Kesadaran Wajib Pajak (X4) & $-0,229$ & 0,375 \\
\hline Adjusted $\mathrm{R}$ Square & 0,281 & \\
\hline Sig. F & 0,000 & \\
\hline
\end{tabular}

Berdasarkan Tabel 5 maka disusun persamaan regresipada penelitian ini adalah sebagai berikut.

$\mathrm{Y}=3,899-1,314 \mathrm{X}_{1}-0,055 \mathrm{X}_{2}+0,504 \mathrm{X}_{3}-0,229 \mathrm{X}_{4}$

Berdasarkan Persamaan 2 dapat diketahui bahwa jika nilai konstanta $(\alpha)$ menunjukkan nilai positif maka memiliki arti jika variabel tingkatppemahaman wajib pajak, sanksi perpajakan, lingkungan wajibppajak dan kesadaran wajib pajak dinyatakan konstan pada angka 0 , maka tingkatkkepatuhan wajib pajak orang pribadi akan tetap terjadi. Berdasarkan persamaan tersebut terlihat bahwa 
terdapat pengaruh positif variabel tingkat pemahaman wajib pajak $\left(\mathrm{X}_{1}\right)$ dan lingkungan wajib pajak $\left(\mathrm{X}_{3}\right)$ pada tingkat kepatuhan wajib pajak orang pribadi (Y) dan pengaruh negatif variabel sanksi perpajakan $\left(\mathrm{X}_{2}\right)$ dan kesadaran wajib pajak $\left(\mathrm{X}_{4}\right)$ pada tingkat kepatuhan wajib pajak orang pribadi (Y).

Analisis regresi linear berganda mengamati goodness of fit (uji kecocokan) dengan melihat koefisien determinasi $\left(\mathrm{R}^{2}\right)$, uji kelayakan model (uji $\mathrm{F}$ ) dan uji hipotesis (uji t). Penelitian yang dilakukan diharapkan memberikan pemahaman yang lebih luas berkaitan dengan tingkat pemahaman wajib pajak, sanksi perpajakan, lingkungan wajib pajak dan kesadaran wajib pajak pada tingkat kepatuhan wajib pajak orang pribadi. Sehingga penelitian ini dapat dijadikan rujukan untuk peneliti-peneliti berikutnya.

\section{SIMPULAN}

Berdasarkan hasil penelitian yang telah dilakukan dengan pembahasanpembahasan pada bab sebelumnya, maka dapat disimpulkan bahwa tingkat pemahaman wajib pajak berpengaruh positif pada tingkat kepatuhan wajib pajak orang pribadi di KPP Pratama Badung Utara, Sanksi perpajakan tidak berpengaruh pada tingkat kepatuhan wajib pajak orang pribadi di KPP Pratama Badung Utara, Lingkungan wajib pajak tidak berpengaruh pada tingkat kepatuhan wajib pajak orang pribadi di KPP Pratama Badung Utara, Kesadaran wajib pajak tidak berpengaruh pada tingkat kepatuhan wajib pajak orang pribadi di KPP Pratama Badung Utara. Sejalan dengan teori atribusi, yang menyatakanbahwa seseorang mencoba untuk menentukan mengapa orang melakukan sesuatu, yaitu atribusi menyebabkan perilaku. Seseorang akan berusaha untuk memahami 
Gek Ayu Putu Intan Permata Dewi dan Ni Ketut Lely Aryani Merkusiwati. Faktor...

mengapa orang lain melakukan sesuatu yang mungkin satu atau lebih atribut menyebabkan perilaku itu.

Berdasarkan hasil penelitian pada bab sebelumnya dan simpulan yang telah diuraikan, maka saran yang dapat diberikan adalahpenelitian selanjutnya diharapkandapat menggunakan populasi pada lokasi yang berbeda, agar hasil penelitian dapat dibandingkan dengan penelitian sebelumnya. Peneliti selanjutnya juga dapat menambahkan variabel lain yang mungkin dapat berpengaruh pada tingkat kepatuhan wajib pajak orang pribadi. Perusahaan diharapkanperlu meningkatkan pemahaman wajib pajaknya, sehingga ke depannya wajib pajak terutama wajib pajak orang pribadi di KPP Pratama Badung Utara lebih patuh lagi dalam melakukan kewajiban perpajakannya.

\section{REFERENSI}

Anggraeni, Lady Ayu. 2017. Pengaruh Kesadaran Wajib Pajak, Lingkungan Wajib Pajak, Sikap Religiusitas Wajib Pajak, dan Kemanfaatan NPWP terhadap Kepatuhan Wajib Pajak. Research Repository of UMY Repository, hal.1-25.

Astuti, Ella Widya. 2015. PengaruhhTingkat PemahamannWajib Pajak, Kualitas Pelayanan Fiskus, Sanksi Perpajakan, Dan Lingkungan Wajib Pajak Terhadap Tingkat Kepatuhan Wajib Pajak Orang Pribadi(Studi Empiris Pada Kpp Pratama Surakarta). Skripsi Sarjana Ekonomi Program Studi Akuntansi pada Fakultas Ekonomi Dan BisnisUniversitas Muhammadiyah Surakarta, Jawa Tengah.

Damajanti, Anita, dan Abdul Karim. 2017. Effect of Tax Knowledge on Individual Taxpayers Compliance. Economics \& Business Solutions Journal, 1 (1), hal.1-19.

Dharma, Maya Tantio dan Stefanus Ariyanto. 2014. Analisis Faktor-Faktor yang Memengaruhi Tingkat Kepatuhan Wajib Pajak Orang Pribadi di Lingkungan Kantor Pelayanan Pajak Pratama, Tigaraksa Tanggerang. Binus Business Review, 5 (2), hal.497-509.

Dewi, Ari Chintya dan Lely Aryani Merkusiwati. 2013. Analisis Tingkat 
Kepatuhan Wajib Pajak atas Pemenuhan Kewajiban Pajak Hotel dan Restoran di Kabupaten Badung Tahun 2011. E-Jurnal Akuntansi Universitas Udayana, 4 (1), hal.110-127.

Fuadi, (2013). Pengaruh Kualitas Pelayanan Petugas Pajak, Sanksi Perpajakan dan Biaya Kepatuhan Pajak Terhadap Kepatuhan Wajib Pajak UMKM. EJournal Tax \& Accounting Review, 1(1), hal.20.

Gambo, El-Maude Jibreel, Abdulasalam Mas'ud, Mustapha Nasidi, dan Oginni Simon Oyewole. 2014. Tax Complexity and Tax Compliance in African Self-Assessment Environment. International Journal of Management Research \& Review, 4 (5), hal.575-582.

Handayani, Ucik, dan Nujmatul Laily. 2017. The Influence of Consciousness, Tax Penalty, and the Quality of Tax Authorities Service on Tax Compliance. Journal of Accounting and Business Education, 1 (2), hal.286-297.

Hidayati, Iva Farida. 2014. Analisis Pengaruh Kesadaran Wajib Pajak, Pengetahuan dan Pamahaman Tentang Peraturan Perpajakan, Efektifitas Sistem Perpajakan, Pelayanan Fiskus dan Sanksi Pajak Terhadap Kepatuhan Wajib Pajak Orang Pribadi, Skripsi S1, Universitas Muhammadiayah Surakarta, Diakses 10 September 2015, dari ums.ac.id.

Kamil, Nurlis Islamiah. 2015. The Effect of Taxpayer Awareness, Knowledge, Tax Penalties and Tax Authorities Services on the Tax Complience. Journal of Finance and Accounting, 6 (2), hal.104-111.

Layata,sSherly, dan Ery Setiawan.22014. Pengaruh KewajibanmMoral, Kualitas Pelayanan, Pemeriksaan Pajak dan Sanksi Perpajakan pada Kepatuhan Wajib Pajak Badan. E-Jurnal Akuntansi Universitas Udayana, 9 (2), hal.540-556.

Lerche, Pletrich. 1980. Efficency of taxtion inindonesia. Bies. VOL. 16.

Mangoting, yYenni dan Cindy Jotopurnomo. 2013. Pengaruh Kesadaran WajibPajak, Kualitas Pelayanan Fiskus, Sanksi Perpajakan, Lingkungan Wajib Pajak Berada terhadap Kepatuhan Wajib Pajak Orang Pribadi di Surabaya. Jurnal Pajak dan Akuntansi, 1 (1).

Mardiasmo, 2016. “Perpajakan”, Edisi Revisi 2013. Jakarta: Andi.

Masruroh, S. 2013. PengaruhhKemanfaatan NPWP, PemahamanwWajib Pajak, Kualitas Pelayanan, dan Sanksi Perpajakan terhadap Kepatuhan Wajib Pajak (Studi Empiris Pada WP OP di Kabupaten Tegal).diponegoro journal of accounting, 2(4). 
Pranata, Aditya, dan Ery Setiawan. 2015.PPengaruh Sanksi Perpajakan,kKualitas Pelayanan dankKewajiban Moral pada Kepatuhan Wajib Pajak.E-Jurnal Akuntansi Universitas Udayana, 10(2), hal.456-473.

Punarbhawa, Bagus dan Lely Aryani Merkusiwati. 2013. Pengaruh Reformasi Administrasi Perpajakan dan Pengetahuan Perpajakan Terhadap Tingkat Kepatuhan Pengusaha Kena Pajak (PKP). E-Jurnal Akuntansi Universitas Udayana, 5 (2), hal.381-397.

Robbins, Stephen P. 1996. PerilakuQOrganisasi: Konsep,KKontroversi dan Aplikasi. Jakarta: Prenhallindo.

Saad, Natrah. 2014. Tax Knowledge, Tax Complexity and Tax Compliance: Taxpayers View. Procedia - Social and Behavioral Sciences, 109, hal.10691075.

Sanders, Debra L.,PPhilip M. J. Reckers \&GGovind S. Iyer. 2008. Influence of Accountability and Penalty AwarenessOon Tax Compliance. American AccountingaAssociation, 30 (2), hal.1-20.

Savitri, Enni dan Musfialdy. 2016. The Effect of Taxpayer Awareness, Tax Socialization, Tax Penalties, Compliance Cost at Taxpayer Compliance with Service Quality as Mediating Variable. Procedia - Social and Behavioral Sciences, 219, hal.682-687.

Syahril, Farid. 2013.pPengaruh Tingkat Pemahaman Wajib Pajak Dan Kualitas Pelayanan Fiskus Terhadap Tingkat Kepatuhan Wajib Pajak PPh Orang Pribadi (Studi Empiris Pada KPP Pratama Kota Solok). Jurnal. Padang: Universitas Negeri Padang.

Sugiyono. 2017. Metode Penelitian Pendidikan Pendekatan Kuantitatif, Kualitatif Dan R\&D. Bandung: Alfabeta.

Susilawati, Evi dan Budiartha. 2013. Pengaruh Kesadaran Wajib Pajak, Pengetahuan Pajak, Sanksi Perpajakan dan Akuntabilitas Pelayanan Publik pada Kepatuhan Wajib Pajak Kendaraan Bermotor. E-Jurnal Akuntansi Universitas Udayana, 4 (2), hal.345-357.

Swistak, Artur. 2015. Tax Penalties in SME Tax Compliance. Financial Theory and Practice, 40 (1), hal.129-147.

Zulaikha, SitiMasruroh. 2013. Pengaruh Kemanfaatan nNPWP, Pemahaman Wajib Pajak, Kualitas Pelayanan, Sanksi Perpajakan terhadap Kepatuhan Wajib Pajak (Studi Empiris pada WP OP di Kabupaten Tegal). Diponegoro Journal of Accounting, 2 (4), hal.1-15. 